\title{
The lytic switch protein of KSHV activates gene expression via functional interaction with RBP-JK (CSL), the target of the Notch signaling pathway
}

\author{
Yuying Liang, ${ }^{1}$ Jean Chang, ${ }^{1}$ Stephen J. Lynch, ${ }^{2}$ David M. Lukac, ${ }^{2}$ and Don Ganem ${ }^{1,3}$ \\ ${ }^{1}$ Howard Hughes Medical Institute and Departments of Microbiology and Medicine, University of California, San Francisco, \\ California 94143-0414, USA; ${ }^{2}$ Department of Microbiology and Molecular Genetics, University of Medicine and Dentistry of \\ New Jersey, Newark, New Jersey 07103, USA
}

The RTA protein of the Kaposi's sarcoma (KS)-associated herpesvirus (KSHV) is responsible for the switch from latency to lytic replication, a reaction essential for viral spread and KS pathogenesis. RTA is a sequence-specific transcriptional activator, but the diversity of its target sites suggests it may act via interaction with host DNA-binding proteins as well. Here we show that KSHV RTA interacts with the RBP-Jк protein, the primary target of the Notch signaling pathway. This interaction targets RTA to RBP-JK recognition sites on DNA and results in the replacement of RBP-JK's intrinsic repressive action with activation mediated by the C-terminal domain of RTA. Mutation of such sites in target promoters strongly impairs RTA responsiveness. Similarly, such target genes are induced poorly or not at all by RTA in

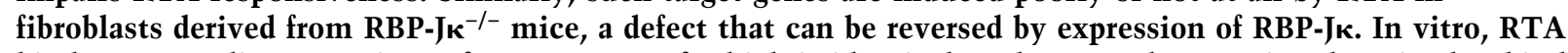
binds to two adjacent regions of RBP-Jк, one of which is identical to the central repression domain that binds the Notch effector fragment. These results indicate that KSHV has evolved a ligand-independent mechanism for constitutive activation of the Notch pathway as a part of its strategy for reactivation from latency.

[Key Words: KSHV; RTA; RBP-Jк; Notch signaling; lytic cycle; transcriptional regulation]

Received April 5, 2002; revised version accepted June 3, 2002.

Herpesviruses are large DNA viruses that are capable of two alternative genetic programs upon infection of host cells. In latent infection, gene expression is limited to a small subset of viral genes, no cellular injury occurs, and no progeny virus particles are produced. In contrast, lytic replication leads to extensive viral gene expression, virion production, and the death of the host cell. Latently infected cells can enter the lytic cycle upon provision of appropriate cellular signals; thus, the pool of latently infected cells represents a reservoir of viral persistence from which infectious virus can be reactivated at later times.

Kaposi's sarcoma (KS)-associated herpesvirus (KSHV) is a lymphotropic herpesvirus that is required for the pathogenesis of KS (Boshoff and Weiss 1998; Sarid et al. 1999; Schulz 1999), a complex neoplasm consisting of proliferating endothelial cells, inflammatory infiltrates, and marked neoangiogenesis (Ensoli and Sturzl 1998). The main reservoir of latent KSHV is the B lymphocyte

${ }^{3}$ Corresponding author.

E-MAIL ganem@cgl.ucsf.edu; FAX (415) 476-0939.

Article and publication are at http://www.genesdev.org/cgi/doi/10.1101/ gad.996502.
(Ambroziak et al. 1995; Blackbourn et al. 2000). Reactivation of virus from this reservoir is a necessary precondition for the spread of KSHV to endothelial cells (Boshoff et al. 1995; Staskus et al. 1997), which then undergo latent infection. Latent infection is thought to enhance the survival of these cells and perhaps promote their proliferation, providing one of the drivers of KS lesion formation. A subpopulation of KS endothelial cells also displays lytic reactivation (Staskus et al. 1997), and there is strong evidence that lytic infection also plays an active role in KS histogenesis. First, drugs that block lytic KSHV infection abort the development of clinical KS (Martin et al. 1999). Moreover, the lytic cycle encodes numerous paracrine signaling molecules (e.g., homologs of IL6 and CC chemokines) that could modulate the inflammatory and angiogenic components of the lesion (Moore et al. 1996; Boshoff et al. 1997; Nicholas et al. 1997; Niepel et al. 1997; Bais et al. 1998). Therefore, elucidating the control of KSHV lytic reactivation is important to the development of a deeper understanding of KS pathogenesis.

The critical viral protein in the switch from latency to lytic reactivation is RTA (replication and transcription activator). Ectopic expression of RTA in latently infected 
B cells triggers efficient lytic reactivation (Lukac et al. 1998; Sun et al. 1998; Gradoville et al. 2000), and spontaneous reactivation is blocked by dominant-negative mutants of RTA (Lukac et al. 1999). RTA is the homolog of the EBV BRLF1 gene product, a sequence-specific DNA-binding protein known to function as a transcriptional activator (Quinlivan et al. 1993; Russo et al. 1996; Zalani et al. 1996; Ragoczy et al. 1998). Not surprisingly, KSHV RTA also acts to promote transcriptional activation of a variety of viral promoters, including those for delayed-early viral genes like TK, SSB, the posttranscriptional activator MTA, and the noncoding polyadenylated nuclear RNA, PAN (Lukac et al. 1998). KSHV RTA contains an N-terminal DNA-binding domain and a C-terminal activation domain (Lukac et al. 1998, 2001; Seaman et al. 1999), and direct, high-affinity binding of purified, recombinant RTA to a site in the PAN promoter has been reported (Song et al. 2001). However, other sites that are activated by RTA in vivo-for example, those in the MTA and RAP (K8, K-bZIP) promoters-display no homology to the PAN promoter site, raising the question of whether RTA might have other modes of DNA interaction, such as binding to cellular DNA binding factors. In fact, interaction with one host protein, the Zn-fingercontaining protein MGC2663, has been reported (Wang et al. 2001), though it is not clear whether this protein targets RTA to DNA or is itself targeted to DNA by RTA.

Here we searched for cellular binding partners of RTA using the yeast two-hybrid screen, and we report that a major cellular interacting protein is RBP-Jк (also known as CSL or CBF-1). RBP-JK is a sequence-specific DNAbinding protein that normally acts to repress transcription and is the principal target of the Notch signaling pathway (Mumm and Kopan 2000). We show that several key lytic-cycle genes contain RBP-Jк sites in their control regions, and that interaction of RTA with RBP-JK results in the targeting of the RTA activation domain to these sites, leading to their Notch-independent activation. Our results suggest that RBP-JK-mediated repression may play a role in the establishment or maintenance of latency and that KSHV has evolved a Notchindependent way to bypass this repression and promote the triggering of lytic reactivation.

\section{Results}

\section{Two-hybrid screen for RTA interacting proteins}

To search for RTA-interacting proteins, we carried out a yeast two-hybrid screen. First, RTA sequences were fused to the GAL4 DNA binding domain (DBD) and tested for their ability to activate a GAL4 UAS-dependent reporter gene. Not unexpectedly, a full-length RTAGAL4/DBD fusion proved to be able to activate the GAL4 reporter gene by itself. Accordingly, we employed in the DBD fusion a deletion mutant of RTA lacking the C-terminal 161 amino acids, which we had earlier shown includes the activation domain of RTA (Lukac et al. 1999). This fusion protein, which did not activate the
GAL4 reporter by itself, was used to screen two oligodT-primed cDNA libraries. The first was constructed from lytically induced KSHV-infected B cells (BCBL-1); the second was a commercial library derived from human placenta. From the BCBL-1 library, we obtained numerous clones of RTA itself, consistent with our earlier demonstration that RTA forms homomultimers in vivo and that this interaction does not involve the C-terminal domain (Lukac et al. 1999). Numerous host cell cDNA clones were obtained from these two libraries, but only one of these was repeatedly isolated from both sources: that encoding a portion of the transcription factor RBP-

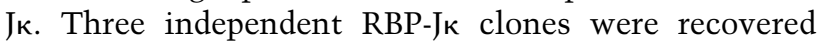
from the induced BCBL-1 library and four from the placenta library. Sequencing of the fusion junction of the smallest clone revealed it to contain the C-terminal 359 amino acids of human RBP-Jк; of the larger clones, several were nearly full-length.

To determine whether the interaction of RTA with RBP-JK was observable in a mammalian cell, we first asked whether the two proteins could coimmunoprecipitate when dually expressed in cells. Accordingly, as shown in Figure 1A, we transfected 293T cells with expression vectors for: (1) a Flag epitope-tagged version of full-length RBP-Jк (Fig. 1A, lanes 2,5,8); (2) a version of RTA bearing a V5 epitope in place of its activation domain (Fig. 1A, lanes $1,4,7)$; or (3) both vectors together (Fig. 1A, lanes 3,6,9). Following extract preparation, complexes were immunoprecipitated with either the Flag $\mathrm{mAb}$ (Fig. 1A, lanes 1-3) or the V5 mAb (Fig. 1A, lanes 4-6), subjected to SDS-PAGE, blotted to membranes, and probed with an anti-V5 mAb (Fig. 1A, lanes 1-6). As shown in Figure 1A, V5-tagged RTA was efficiently precipitated with anti-Flag antibody when cotransfected with Flag-tagged RBP-Jк (Fig. 1A, lane3), but not when expressed in the absence of RBP-Jк (Fig. 1A, lane1).

To confirm that this interaction occurs in authentically infected cells, we examined the coprecipitation of endogenous RBP-Jк with virus-encoded wild-type (WT) RTA in lymphoma cells (BCBL-1) bearing latent KSHV genomes (Fig. 1B). BCBL-1 cells were either untreated (Fig. 1B, U lanes) or TPA-induced (Fig. 1B, I lanes) to activate lytic KSHV replication. Extracts were then precipitated with rabbit polyclonal antibody to RBP-Jк (Fig. $1 \mathrm{~B}$, lanes 1,2 ), and the precipitates were examined by SDS-PAGE and immunoblotting with rabbit anti-RTA antibody (Lukac et al. 1999). A band at $\sim 120 \mathrm{kD}$ that exactly comigrates with authentic RTA (Fig. 1B, lanes $5,6)$ is seen when induced cells are immunoprecipitated with anti-RВРЈк antibody; use of an irrelevant rabbit antibody (anti-NIK; Fig. 1B, lanes 3,4) does not precipitate RTA. [The faint band of RTA visible in the anti-RBPJк immunoprecipitate in untreated cells (Fig. 1B, lane 1) is due to the background of spontaneous lytic reactivation in this cell line, as attested to by the presence of RTA detected in this sample in Fig. 1B, lane 5]. As an additional indication of the specificity of RTA precipitation by anti-RBPJк antibody, we note that when RTA is expressed in the RBP-Jк null cell line OT11 (Fig. 1B, lanes 


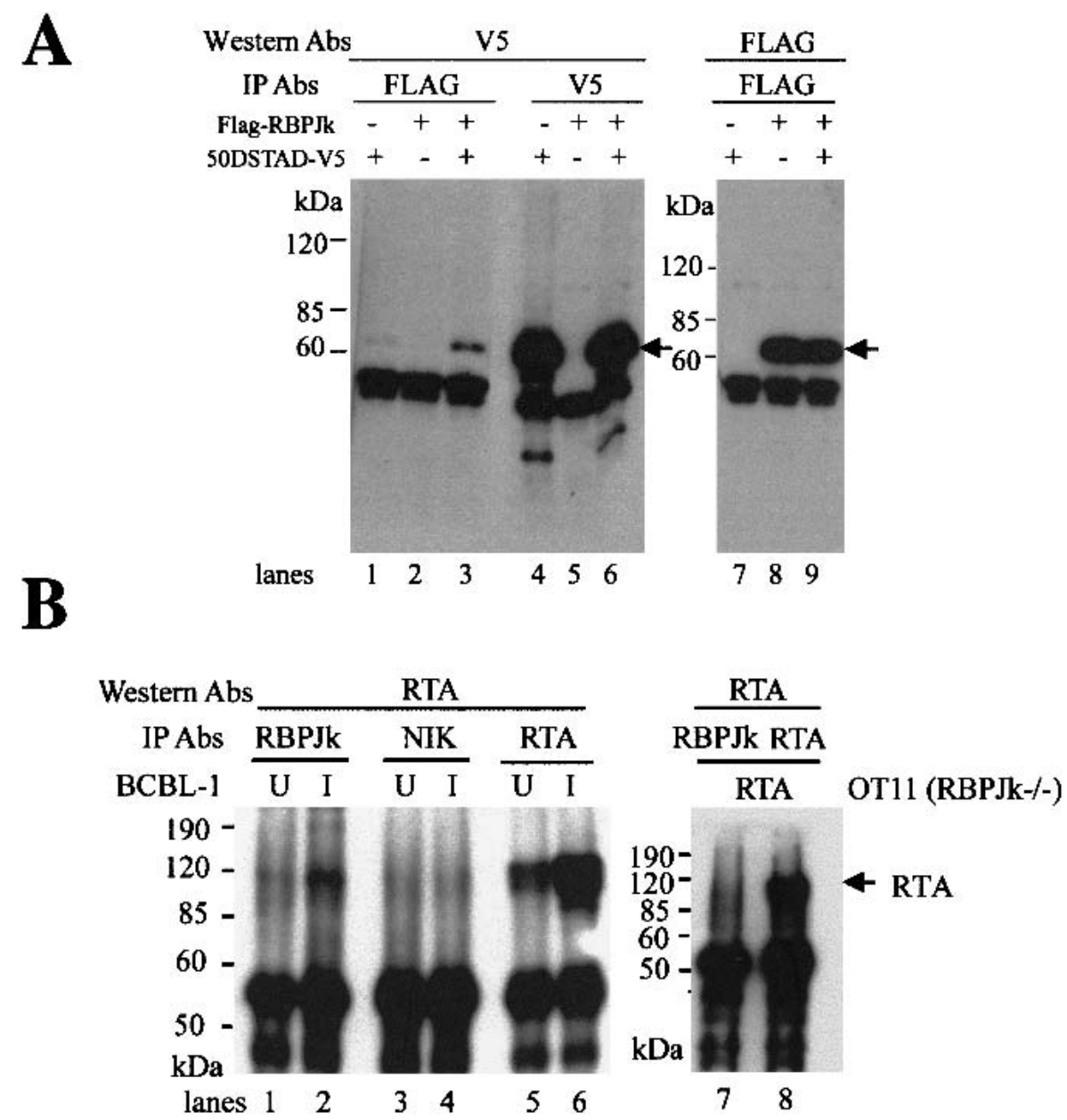

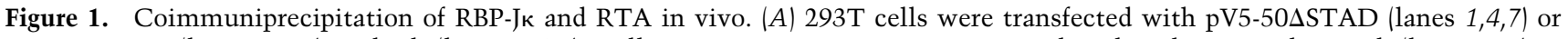
pFLAG-RBPJк (lanes 2,5,8), or both (lanes 3,6,9). Cell extracts were immunoprecipitated with either anti-Flag mAb (lanes 1-3) or anti-V5 mAb (lanes 4-6), and analyzed by Western blot with either anti-V5 mAb (lanes 1-6) or anti-Flag mAb (lanes 7-9). (B) BCBL-1 cells were either mock-induced (labeled $U$, lanes 1,3,5) or TPA-induced (labeled I, lanes 2,4,6). Cell extracts were immunoprecipitated with anti-RBPJк (lanes 1,2), anti-NIK (NFkB-inducing kinase) (lanes 3,4), or anti-RTA (lanes 5,6) antibodies. As a control, RBPJк null cells (OT11) were transfected with pcDNA3-Flc50. Cell extracts were immunoprecipitated with either anti-RBPJK (lane 7) or anti-RTA (lane 8) Ab. All immunoprecipitates were analyzed by Western blot with anti-RTA antibody.

7,8), no RTA is precipitated by anti-RBPJк antibody (Fig. 1B, lane 7).

\section{$R B P-J \kappa$ recognition sequences can serve as RTA-response elements}

RBP-JK is known to recognize the sequence 5' GTGGGAA 3' (Tun et al. 1994). To test whether the interaction of RTA and RBP-JK has functional significance, we asked whether a reporter gene driven by this sequence could be activated by coexpression of RTA. Three copies of the RBP-JK recognition element were cloned in tandem in the sense orientation, $120 \mathrm{bp}$ upstream of a TATA box that directed basal expression of a luciferase (LUC) reporter. (For comparison, we also employed a plasmid bearing four tandem copies of the site cloned in the opposite orientation.) In parallel, we cloned three copies of a mutant RBP-Jк element into the same parental vector, again in both orientations; the introduced mutation is known to ablate RBP-Jk binding in vitro. The human endothelial cell line SLK was transfected with WT or mutant RBP-J $\kappa$ reporters, in the presence of either an RTA expression vector or an isogenic empty vector control. As summarized in Figure 2A, the vectors bearing the RBP-JK site in either orientation were induced 70110-fold by RTA coexpression; in contrast, mutational inactivation of the RBP-Jк recognition site completely ablated RTA-responsiveness irrespective of the orientation of the site.

To more directly implicate RBP-Jк in this RTA response, we obtained a line of mouse embryo fibroblasts

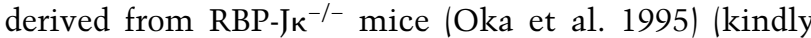
supplied by Dr. T. Honjo, Kyoto University, Japan). As shown in Figure 2B, transfection of WT RBP-JK/LUC reporters into these cells results in very low LUC expression, and this expression is not enhanced by cotransfec- 
A

\section{SLK}

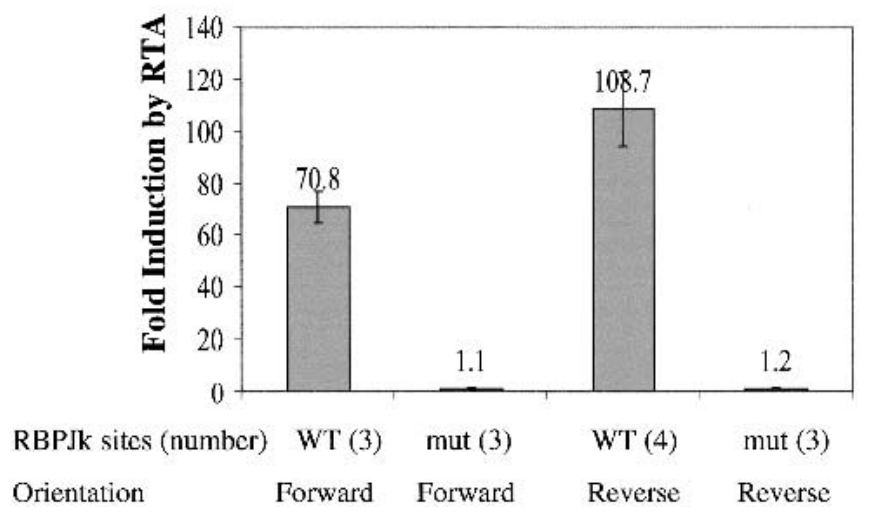

B

\section{OT11 (RBPJk-/- MEF)}

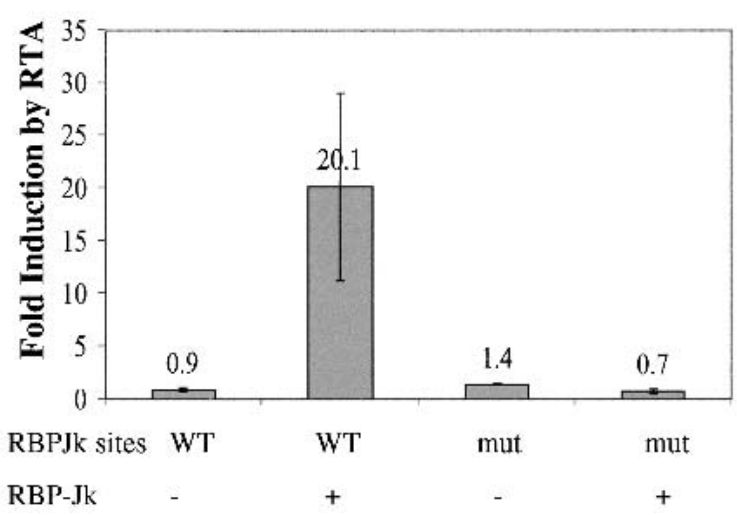

Figure 2. RTA activates promoters containing RBP-Jк recognition sequences in WT (SLK) but not RBPJк-null cell line (OT11). (A) SLK cells were cotransfected with 0 to $1 \mu \mathrm{g}$ of pcDNA3-Flc50 and $0.5 \mu \mathrm{g}$ of luciferase reporter constructs driven by promoters containing tandem repeats (indicated in number) of either WT or mutant (mut) RBPJк binding site in either orientation (forward or reverse). (B) OT11 cells were cotransfected with 0 to $0.5 \mu \mathrm{g}$ of pcDNA3-Flc50 and $0.5 \mu \mathrm{g}$ of luciferase reporter constructs containing three copies of WT or mutant (mut) RBPJк binding site in forward direction, with $(+)$ or without $(-) 1 \mu \mathrm{g}$ of pcDNA3.1-RBPJк. Luciferase assay was performed as described in Materials and Methods. The maximal transactivation by RTA was plotted for each promoter, with the error bars representing standard deviations of the results from at least two independent experiments.

tion of RTA (induction ratio 0.9). This indicates that RTA itself cannot directly activate an RBP-Jк site. However, if RBP-JK is supplied from a transfected plasmid, $\mathrm{RTA}$ responsiveness is strongly restored to vectors bearing a WT RBP-Jк site (induction ratio 20); this induction is ablated by mutational inactivation of the RBP-JK binding site, irrespective of the presence or absence of RBP-JK (Fig. 2B). Taken together, these findings strongly suggest that RTA is capable of functional interaction with RBP-JK to promote activation via an RBP-Jк recognition element.

\section{$R T A / R B P-J \kappa$ interactions in authentic viral promoters}

To determine whether this form of regulation occurs in the viral genome, we screened the KSHV genomic sequence for candidate RBP-JK sites, with particular attention to sites mapping in the regulatory regions of viral genes known to be responsive to RTA regulation. Consensus RBP-Jк sites were identified within the regulatory regions of numerous genes, including PAN (polyadenylated nuclear RNA), ORF 57 (encoding the mRNA transcript accumulation function, MTA), major ssDNAbinding protein (SSB), and thymidine kinase (TK). Three of these genes were chosen for study (PAN, MTA, and SSB).

Figure 3A schematically depicts the organization of the relevant portions of the MTA and SSB promoters, indicating the location of the predicted RBP-JK recognition element within each. In the MTA promoter, our earlier work (Lukac et al. 2001) established that deletion to -106 preserves RTA-inducibility, while deletion to -54 abolishes it, thereby defining a $52-$ bp sequence that confers RTA responsiveness. The RBP-Jк site falls within this region, in the antisense orientation relative to the MTA ORF. The 106-bp promoter element of MTA and a $1.2-\mathrm{kb}$ fragment bearing the full SSB promoter were cloned 5' to a LUC reporter and assayed for RTA responsiveness in isogenic mouse embryo fibroblasts (MEFs)

Figure 3. RTA/RBP-Jк interactions in authentic viral promoters. (A) Promoters of MTA (ORF57) and SSB contain RBPJK recognition sites. The sequences of MTA and SSB promoters are shown, with the RBPJк recognition site outlined by an empty box (orientation: reverse in MTA promoter and forward in SSB promoter). The previously identified 52-bp RTA-response element (50RE) between -106 and -54 nt of MTA promoter is underlined. (B) RTA transactivation of MTA or SSB promoters (WT or RBPJк site-mutated) in OT13 (WT) or OT11 $\left(\mathrm{RBPJ}^{-/-}\right)$cell line. OT13 or OT11 cells were cotransfected with 0 to $0.5 \mu \mathrm{g}$ of pcDNA3-Flc50 and $0.5 \mu \mathrm{g}$ of luciferase reporter constructs driven by MTA promoter, MTA promoter with mutations at RВРЈк recognition site (see Materials and Methods) (MTAmut), SSB promoter, or SSB promoter with mutations at RBPJк recognition site (SSBmut). In OT11 cells, RTA transactivation was tested in the absence (-) or presence $(+)$ of $1 \mu \mathrm{g}$ of cotransfected pcDNA3.1-RBPJк. (C) Schematic representation of mutants of PAN promoter and their responsiveness to RTA transactivation in SLK and OT11 cells. The RTA-response element (50RE) identified by Song et al. (2001) extends from -69 to -38 bp upstream of RNA start site. Mutation on 50RE, represented by a hatched box, was created by replacing the 12 -nt sequence ( -67 to -56 ) with linker sequence TATCATATGATA. RВРJк recognition site was from -818 to -824 in reverse direction. Mutation of RBPJк recognition site (changes of TTCCCACGG to TTCCAAGCC) is represented by the gray box. RTA transactivation on the WT and mutant PAN promoters in SLK and OT11 cells was measured in the same way as in (B). 


\section{MTA(ORF57) promoter}

50RE RBP-JK ITGCCAGCAAGTGTAACAATAATITCCCAOGGCCCATTTTCGTTTGTGGTACCAGTGGGACTGGCCAGTTAAT 81968 TATA CCCACTATATAACCTGGCTGCCAGGTTCCCAAAATAGCCCGCGGCATACGGCTCACTTCCCCCCACATTCCCCC 82042 CGTGCACAATATAAGAACCAAAGGACATG

\section{SSB promoter}

RBP-Jk

TGCGTTTCTTTGTATAAAATACGCGTGTGGGAAAGCGACAGAAGGGGGCGGCGTTTCCATATGAGGCCAAGTGC 3056 ATTGGCTATTTTAGGGGCGGTGACCACGCACTATAGTGCGCGGTGTGGCAGAAAATTCACACCGTATATAAACA 3130 AGGAAAGGGGACTCTGCGCGCTTAAGCGCCAAGCCATTATACACACGGGTTTTTTGTTGTCTTGGCCAATCGTG 3204 TCTCCATG

B

OT13 (RBPJk+/+ MEF)

OT11 (RBPJk-/- MEF)
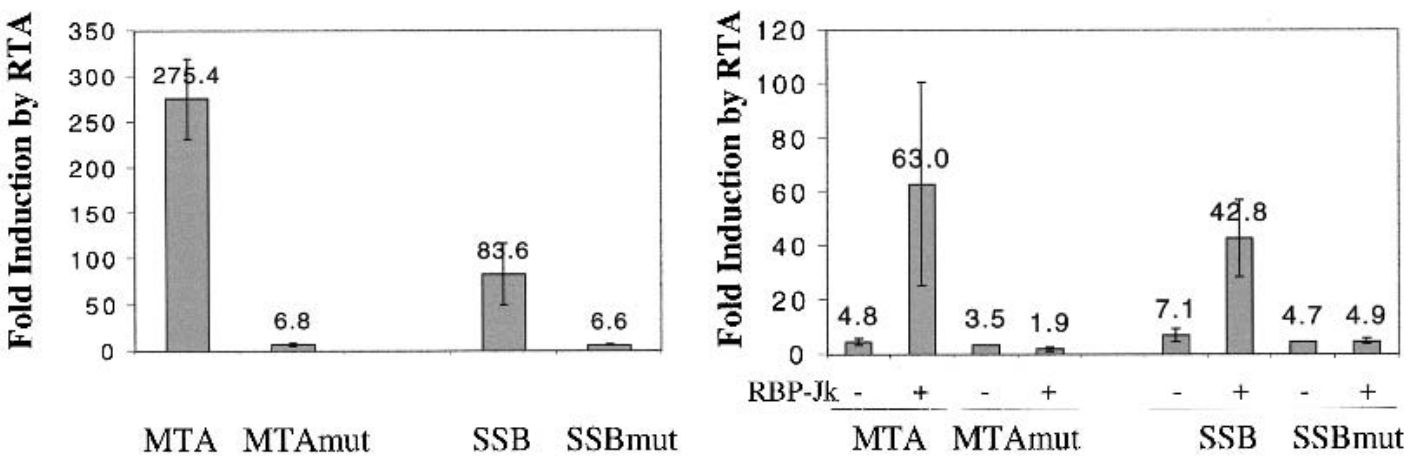

C

MTA MTAmut SSB SSBmut

MTA MTAmut.

SSB SSBmut

pGL3-PAN1450

pGL3-PAN1450-50RE

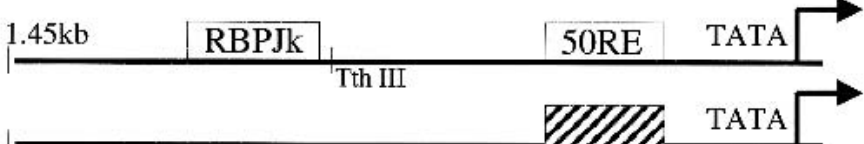

pGL3-PAN706

pGL3-PAN706-50RE

pGL3-PAN1450-RBP

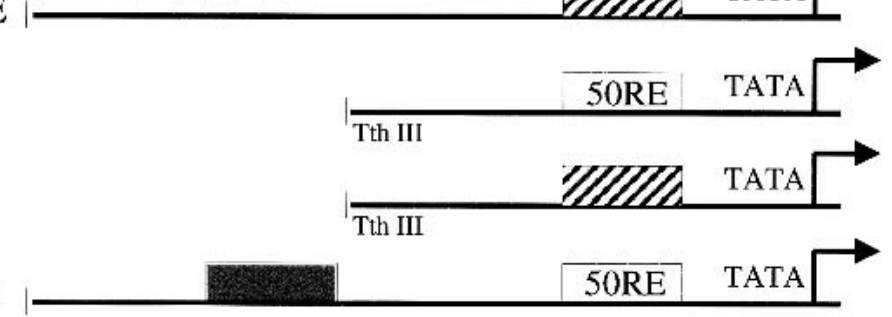

SLK cells

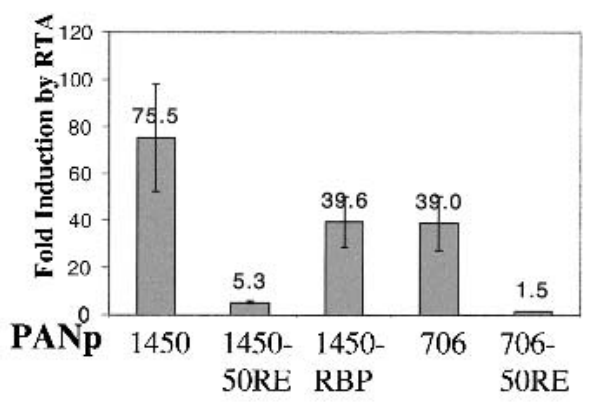

OT11 (RBPJk-/- MEF)

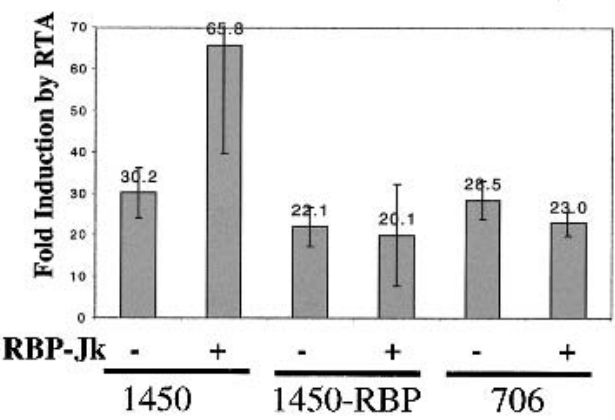

(Figure 3 legend on facing page) 
that were either RBP- $\mathrm{JK}^{+/+}$(line OT13) or RBP- $\mathrm{JK}^{-/-}$(line OT11). In addition, we engineered mutations into the core RBP-Jк recognition motif in each promoter and analyzed these in parallel. As shown in Figure 3B, in WT cells the MTA promoter supports robust (275-fold) induction by RTA, and introduction of the RBP-Jк mutation results in a severe loss of inducibility (to an induction ratio of only 6.8 ). In the $\mathrm{RBP}-\mathrm{JK}^{-/-}$cells, RTA-responsiveness of the WT construct is reduced to levels (mean, 4.8-fold) comparable to that observed in $\mathrm{WT}^{+/+}$ cells transfected with the mutant reporter (Fig. 3B; mean, 6.8-fold). RTA inducibility can be restored to the RBP$\mathrm{J \kappa}^{-/-}$cells by transfection of $\mathrm{RBP}-\mathrm{J} \kappa$, but this restoration is ablated by point mutation in the RBP-JK recognition site (Fig. 3B). Quite similar results were found in the SSB promoter. In normal MEF cells, the WT promoter fragment conferred an 80-fold induction of Luc expression in the presence of RTA, while a single point mutation in the $\mathrm{RBP}-\mathrm{J}_{\kappa}$ recognition site reduced this induction to only 6.6-fold (Fig. 3B). Similarly, the WT SSB promoter could be induced only 7-fold by RTA in RBP-J $\kappa^{-/-}$cells, and this defect could be substantially corrected by provision of RBP-J $\kappa$ from a cotransfected plasmid, but only if the SSB promoter contained an intact RBP-JK site (Fig. 3B). Note that in both promoters, low-level RTA induction (1.9-4.9-fold) was still observed in the complete absence of RBP-Jк, suggesting that additional modes of RTA activation exist (see below). Nonetheless, RBPJкdependent mechanisms appear to be dominant in these promoters.

The PAN promoter provides additional insight into the varieties of RTA regulation. Song et al. (2001) mapped an RTA (ORF 50)-response element (50RE) from -69 to -38 bp 5 ' to the PAN RNA start site and showed that this site mediates high-affinity binding by purified, bacterially-expressed RTA. Figure 3C shows a collection of mutants of the PAN promoter we independently constructed. In agreement with the findings of Song et al. (2001), in SLK endothelial cells a promoter fragment of 706 bp (PAN 706; Fig. 3C) confers 40-fold RTA-inducibility on a LUC reporter, and this induction is completely abolished by linker substitution within the element they previously identified (PAN 706, 50RE ${ }^{-}$). However, when a larger $(1.45-\mathrm{kb})$ fragment of the PAN promoter is used (PAN 1450, Fig. 3C), RTA-inducibility reaches nearly 80 -fold, and even with mutation of the downstream RTA-binding site, RTA-induction in the larger construct is still fivefold (PAN 1450, 50RE'). Inspection of the DNA sequence of the PAN regulatory region between -706 and $-1450 \mathrm{nt}$ reveals a single consensus RBP-JK site, positioned in the antisense orientation relative to the PAN transcript. We constructed a 4-bp mutation (termed $\mathrm{RBP}^{-}$) in this site in PAN 1450, and assayed the WT and mutant constructs in both SLK cells and in RBP- JK ${ }^{-/-}$(OT11) MEF cells (Fig. 3C). In SLK cells, the $\mathrm{RBP}^{-}$mutation in PAN 1450 reduced RTA induction to levels identical to that seen in PAN 706. In RBP-Jк null cells, RTA was still able to induce the PAN 1450 promoter $\sim 30$-fold, an amount equivalent to that observed with PAN 706 (Fig. 3C). Cotransfection of RBP-
J火 into OT11 restored full inducibility to the PAN 1450 element but not to the PAN 706 element; introduction of the RBP-Jк site mutation into PAN 1450 ablated this augmented induction (Fig. 3C). Thus, the PAN promoter exemplifies both forms of RTA regulation-induction by direct DNA binding and by RBP-JK interaction-in a single gene. In this case, direct DNA binding appears to be the dominant determinant of induction, with RBP-Jкdependent mechanisms playing a secondary role.

\section{Mapping the interaction domains in RBP-Jк and RTA}

To define the regions of RBP-J $\kappa$ that are involved in interactions with RTA, we examined the ability of WT and truncated versions of RBP-Jк synthesized in vitro to interact with a full-length RTA-GST fusion protein immobilized on glutathione-Sepharose beads. The RBP-Jк regions indicated in Figure 4 were translated in rabbit reticulocyte lysates in the presence of ${ }^{35} \mathrm{~S}$-methionine, then incubated with the immobilized RTA-GST fusion (or control GST alone). After extensive washing, bound RBP-JK was recovered from the beads and examined by SDS-PAGE. As shown in Figure 4, RBP-Jк constructs containing only aa $1-100$ and $1-150$ bound poorly to RTA (clones AD and AC), while one containing aa 1-180 (clone $\mathrm{AB}$ ) bound efficiently and specifically to RTA. However, a nonoverlapping construct (clone $\mathrm{BE}$ ) bearing aa 179-500 also bound efficiently, as did clone BF, bearing region 179-360 (corresponding to the binding domain for Notch and EBNA2; see Discussion), albeit with somewhat reduced efficiency. Taken together, these studies suggest that there are two contiguous but separable binding regions on RBP-Jк, one of which (the central repressor domain) overlaps with the binding site for RBP-Jк's physiologic effector (Notch) and one of which (the N-terminal domain) does not.

A similar approach was used to define the region(s) of RTA that are required for interaction with RBP-Jк. Here, various truncation mutants of RTA were translated in vitro with ${ }^{35} \mathrm{~S}$-methionine and examined for their ability to bind a full-length RBP-J//GST fusion protein. Figure 5 shows that, as expected from the 2-hybrid analysis, the C-terminal activation domain of RTA is not required for this interaction: mutants $\triangle \mathrm{STAD}$ and $\mathrm{AF}$, which lack this domain, bind normally. The smallest fragment capable of binding RBP-J $\kappa$ is a centrally located region spanning aa 170-400 (construct BF; Fig. 5). This region, which is missing most of the DNA binding domain, contains a leucine-rich repeat region (aa 246-270), deletion of which (e.g., in construct DE) severely compromises RBP-JK binding.

The RTA/RBP-Jк complex binds to DNA containing RBP-JK recognition elements. The simplest explanation for the finding (Figs. 2 and 3 ) that RTA mediates activation in a fashion dependent upon both RBP-Jк and the

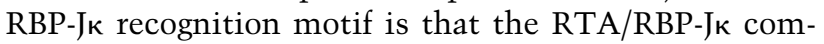
plex can directly bind to this motif, via recognition sequences encoded by RBP-Jк. To test this, we incubated a ${ }^{32} \mathrm{P}$-labeled oligonucleotide corresponding to the canonical RBP-Jк recognition motif with rabbit reticulocyte ex- 

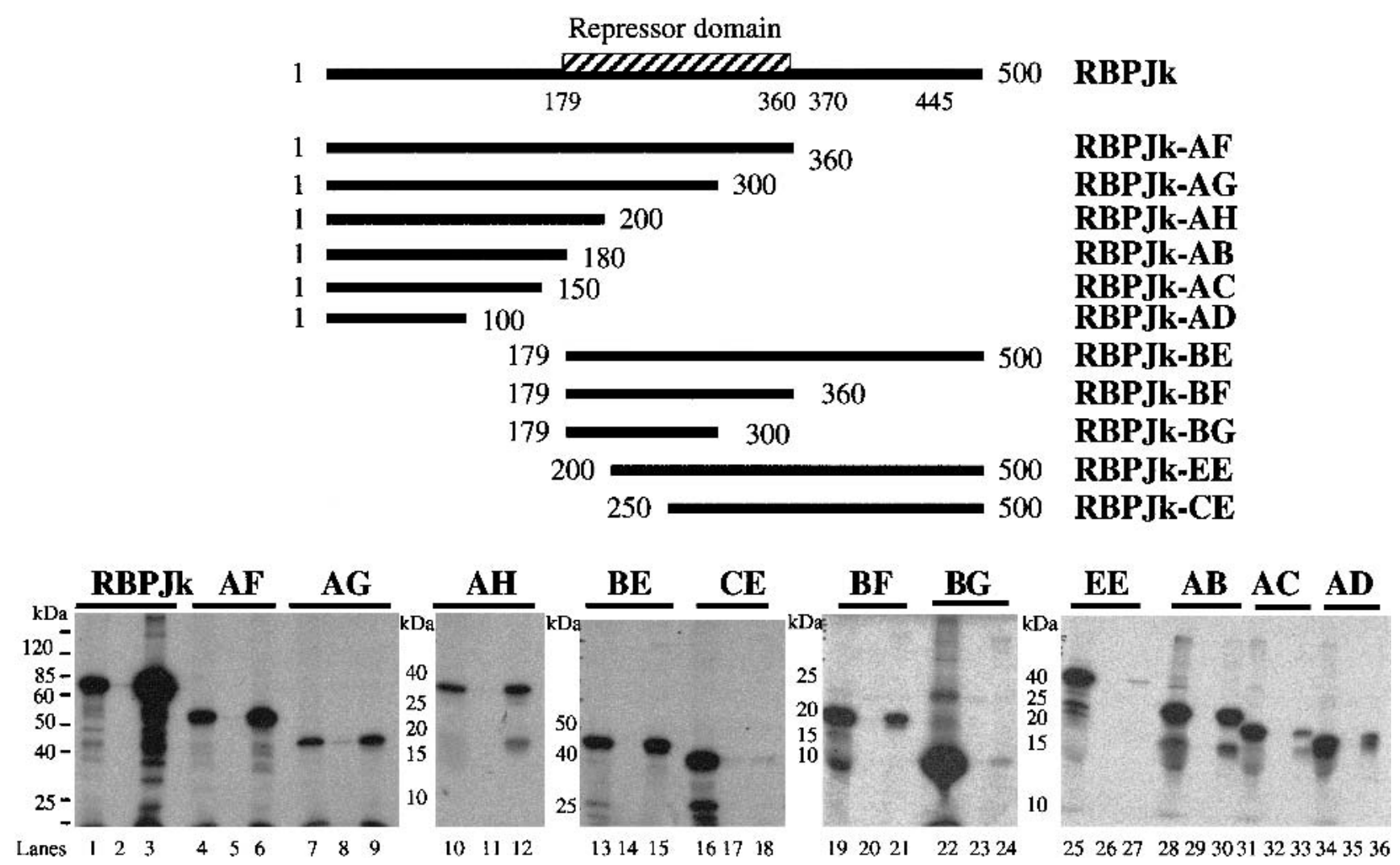

Figure 4. Mapping the RTA-interaction domains in RВPJк. The repressor domain, represented by the hatched box, was previously identified (Hsieh and Hayward 1995) to extend from aa 179 to 360. Truncated versions of RBPJк (AF, AG, AH, AB, AC, AG, BE, BF, $\mathrm{BG}, \mathrm{EE}$, and CE) are shown schematically along with the positions of the start and end residues. All constructs (directed under T7 promoter) were ${ }^{35}$ S-labeled by in vitro translation (1/50 loading; lanes 1,4,7,10,13,16,19,22,25,28,31,34), bound to either GST (lanes $2,5,8,11,14,17,20,23,26,29,32,35$ ) or GST-50 $\Delta$ STAD (lanes 3,6,9,12,15,18,21,24,27,30,33,36) beads, washed with NETN buffer, and separated by SDS-PAGE.

tracts that had been programmed with mRNA for RTA, RBP-Jк (Flag epitope-tagged), or both. After incubation, complexes were assayed by electrophoretic mobility shift assays (EMSAs) and autoradiography. Figure 6 shows that incubation of the probe with lysates expressing RBP-Jк leads to strong complex formation (cf. Fig. 6, lanes 1 and 5); these complexes can be competed by unlabeled WT (Fig. 6, lane 12) but not mutant (Fig. 6, lane 13) RBP-JK recognition sequences. In addition, these complexes can be supershifted by incubation with antiFlag mAb (data not shown). In contrast, lysates expressing RTA alone generated no shift (Fig. 6, lanes 3,4), confirming the absence of endogenous RBP-Jк from the lysate and indicating that RTA does not bind this site-a result that accords well with the failure of RTA to acti-

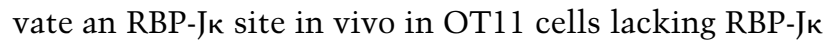
(Fig. 2).

Incubation of the DNA with extracts programmed with both RTA and RBP-Jk mRNA (Fig. 6, lanes 9,10) revealed a complex of lower mobility than that produced by RBP-Jк alone, presumably corresponding to the ternary complex between RTA, RBP-JK, and DNA. Consistent with this, formation of this complex was blocked in the presence of a polyclonal rabbit antiserum to RTA
(Fig. 6, lane 11). To further validate ternary complex formation, we translated mRNA for a V5 epitope-tagged C-terminal deletion mutant of RTA ( $\triangle$ STAD-V5) together with RBP-Jк mRNA. These proteins resulted in a shifted complex that had a faster mobility than the ternary complex containing WT RTA (compare the asterisked bands in Fig. 6, lanes 6,7 and those in lanes 9,10). Addition of anti-V5 mAb to such reactions resulted in supershifting of the band to a slower mobility species (Fig. 6, lane 8).

\section{Discussion}

These data demonstrate that the RTA lytic switch protein of KSHV can functionally interact with the host transcriptional regulator RBP-Jк, and underscore the variety of ways in which this versatile viral protein can act. It can bind DNA directly and mediate activation of the corresponding promoter (Song et al. 2001), or it can be targeted to sites lacking direct recognition elements by host DNA-binding factors such as RBP-Jк. Some genes (e.g., PAN) are regulated by both mechanisms. Additional levels of complexity also exist. For example, we 
Liang et al.
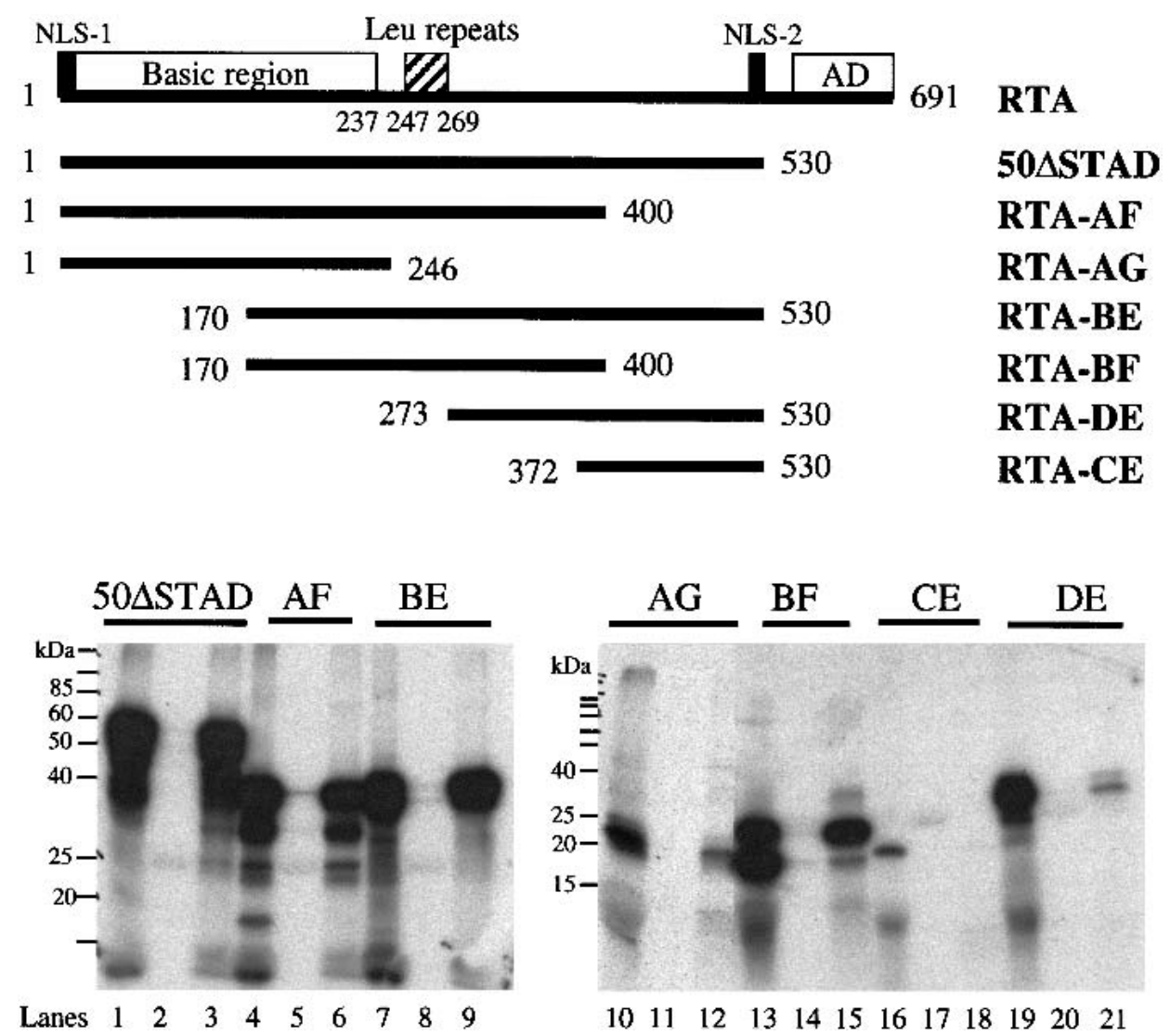

Figure 5. Mapping the RBP-Jк-interaction domains in RTA. The conserved domains of RTA are shown schematically: the basic region (1 to $237 \mathrm{aa}$ ), leu repeats (247 to $269 \mathrm{aa}$ ), activation domain (AD), and two nuclear localization sites (NLS-1 and NLS-2). Truncated versions of RBP-JK (50ASTAD, RTA-AF, RTA-AG, RTA-BE, RTA-BF, RTA-DE, and RTA-CE) are shown schematically along with the positions of the start and end residues. All constructs (directed under T7 promoter) were ${ }^{35}$ S-labeled by in vitro translation (1/50

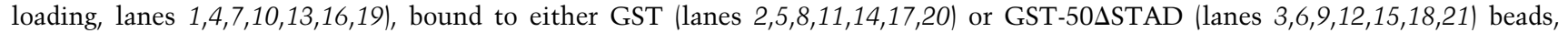
washed with NETN buffer, and separated by SDS-PAGE.

recently found that some RTA response sites (e.g., that in the MTA promoter) are composite sites, in which RTA delivered to the site as an RTA/RBP-Jк complex makes additional contacts with sequences adjacent to the canonical RBP-Jк site (S. Lynch, Y. Liang, D. Ganem, and D. Lukac,unpubl.).

RBP-JK is a member of the CSL (for mammalian CBF1/RBP-Jк, Drosophila $\underline{\mathrm{Su}}(\mathrm{H})$, and C. elegans Lag-1) group of sequence-specific transcriptional repressors. In the ground state, CSL proteins recruit (via their central domain, aa 179-361 in RBP-JK) a number of corepressor proteins (e.g., SMRT and CIR) (Kao et al. 1998; Hsieh et al. 1999) that recruit histone deacetylases (e.g., HDAC1 and 2). But CSL proteins are also regulated by an important signaling system, the Notch pathway, which governs many cell fate decisions in the development of organisms from flies to humans (Mumm and Kopan 2000). Notch proteins are transmembrane receptors; when they interact with one of their several ligands, a cascade of proteolytic reactions takes place, ultimately liberating a fragment of their cytosolic tail (the Notch intracellular domain or NICD). (For review, see Weinmaster 2000; Panin and Irvine 1998). This fragment is transported to the nucleus via its two NLS elements, where it can then interact with RBP-JK (CSL) via its N-terminal RAM domain and adjacent ankyrin-like repeats (Tani et al. 2001). This interaction is thought to occur primarily via binding to the central (repressive) domain of RBP-Jк (Hsieh and Hayward 1995), one of the two regions we have found to mediate interaction with RTA (Fig. 4). This binding reaction has two important consequences. First, it can displace the repressive factors recruited by this region. Second, the NICD also contains an activation domain, and the recruitment of this domain to the RBPJк site allows for direct activation via interactions with the histone acetyltransferases PCAF, GCN5 (Kurooka and Honjo 2000), and p300 (Oswald et al. 2001). Despite its lack of sequence homology with Notch, the properties of RTA described here display striking functional parallelism with those of the NICD, and suggest that RTA induction represents a form of ligand-independent activation of the Notch pathway. Of course, the added ability of RTA to directly bind DNA means that the pattern of downstream gene activation by RTA will likely be overlapping but nonidentical to that produced by Notch.

RTA is not the only viral regulator known to mimic 


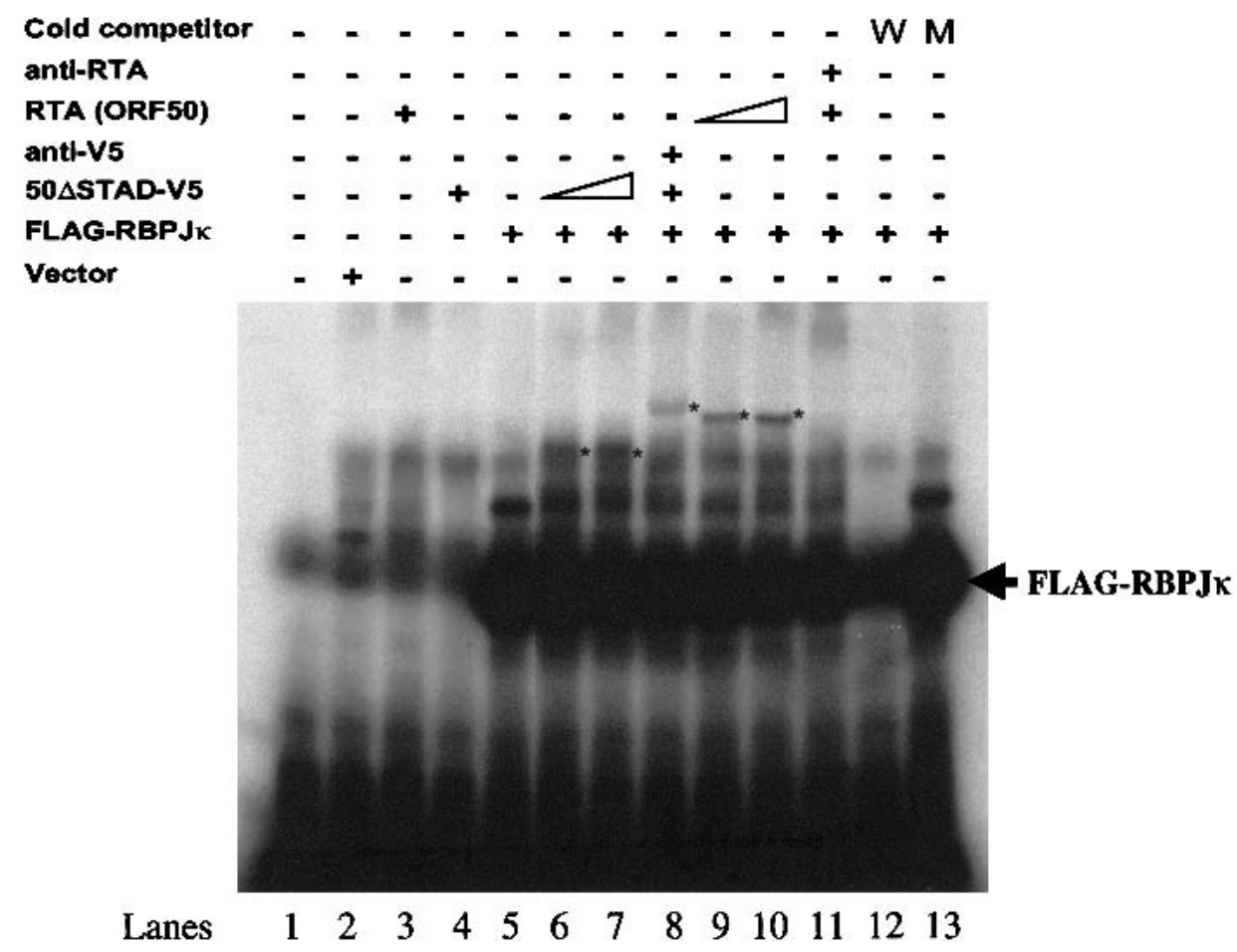

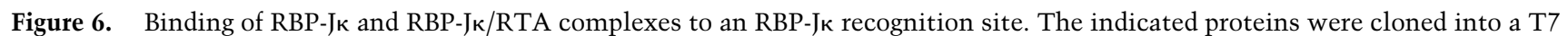
transcription vector and expressed in a rabbit reticulocyte lysate (RRL). The RRL extracts programmed with the indicated vectors were added to a ${ }^{32} \mathrm{P}$-labeled oligonucleotide corresponding to a canonical RBP-Jк site, and complexes were analyzed by EMSA. Arrow indicates the position of RBP-JK/DNA complex. "Vector" refers to lysate programmed with an empty T7 transcription vector. WT, wild-type RBP-Jк site; MT, mutant RBP-Jк site.

the Notch pathway. The EBNA-2 and -3 proteins of Epstein-Barr Virus (EBV) have long been known to interact with RBP-Jк (Grossman et al. 1994; Hsieh and Hayward 1995; Johannsen et al. 1996), and recent work suggests that the 13S isoform of adenovirus E1A is also capable of such interactions (Ansieau et al. 2001). The regulation of Notch signaling by EBV's EBNA proteins affords an instructive comparison with that effected by KSHV RTA. EBV is a human herpesvirus distantly related to KSHV. Latent EBV infection is linked to several B cell lymphoproliferative disorders, and EBNA-2 expression by EBV is necessary for B lymphocyte immortalization in vitro. Unlike RTA, EBNA-2 has no intrinsic DNA-binding activity and can bind DNA only via protein-protein interactions with DNA-binding factors, notably RBP-Jк (Grossman et al. 1994; Hsieh and Hayward 1995; Hsieh et al. 1996, 1997) and Pu.1 (Johanssen et al. 1995). The EBNA-2 interaction domain of RBP-Jк maps to aa 179361 , identical to one of the two regions we find to interact with KSHV RTA (Hsieh et al. 1995, 1996). Interactions of EBNA-2 with this region relieve repression and, like the cognate RTA interactions, actively mediate activation of target promoters. The EBNA-3 proteins are a family of related polypeptides that can also bind to RBPJ $\kappa^{\prime}$ s central domain; they compete with EBNA-2 for this region, providing a form of regulation of EBNA-2's activating activity (Johannsen et al. 1996; Waltzer et al. 1996; Zhao et al. 1996). However, there is little amino acid homology between EBNA-2 or EBNA-3 and KSHV; in particular, the WW motif in EBNA-2 that is essential for RBP-Jк interaction has not been conserved in RTA. Moreover, a critical distinguishing feature is that the EBV and KSHV genes are expressed in opposite phases of the viral life cycle-EBNA-2 (and the EBNA-3s) in latency, RTA in lytic replication.

The RBP-JK-dependent activation of genes by EBNA-2 is thought to play an important role in the biology of EBV latency, leading to upregulation of CD23, c-fgr, and other host and viral functions that affect the growth phenotype of the latently infected cells (Ling et al. 1994; Hsieh et al. 1997). Given its restriction to the lytic cycle, activation of Notch signaling by KSHV RTA may be expected to have rather different biological consequences. Since these cells are destined to die, proliferative signals emanating from this pathway (Capobianco et al. 1997; Aster and Pear 2001) are not likely to directly contribute to tumorigenesis. However, activation of host genes by this pathway might have important consequences for the viral replicative program. For example, in some B cell lines, Notch signaling triggers G1 arrest (and subsequent apoptosis; Morimura et al. 2000). Cell cycle arrest is a common feature of herpesviral immediate-early proteins (Flemington 2001), and is thought to be beneficial to the virus by preventing cellular $S$ phase from competing with the viral genome for essential nucleotides and other precursors. Since the viral genome encodes inhibitors of 
apoptosis (Sarid et al. 1997; Cheng et al. 1997), the proapoptotic action of Notch activation in B cells would be suppressed in the context of lytic reactivation, leaving the G1 arrest as its principal consequence.

Our finding that viral lytic-cycle genes can be controlled in a Notch-like fashion has additional biological implications. Lytic-cycle genes are normally silenced during latency, and it is traditionally thought that this is due largely to the absence of virally encoded positive regulators. However, our discovery that several key lytic genes have been wired by viral evolution into a host program of active (and reversible) repression suggests that negative regulatory loops can contribute to the establishment or maintenance of latency.

Our data raise the possibility that Notch signaling, by mimicking the effects of RTA, might allow RTA-independent lytic induction. At present, however, we consider this unlikely: Since RTA can directly activate viral genes by RBP-Јк-independent mechanisms, Notch signaling is unlikely to evoke the full repertoire of lytic viral gene expression. However, it seems plausible that exogenous Notch signaling could induce expression of a selected subset of lytic-cycle genes during latency. That is, the latency program might not be static, as it is often depicted in textbooks, but vary from tissue to tissue or even moment to moment based upon the presence or absence of environmental signals like Notch ligands. Depending upon the magnitude of such induction, the results could range from no demonstrable phenotype to abortive lytic infection with cell injury or death (in the absence of virus production). This is important because many KSHV lytic cycle genes encode paracrine signaling molecules that can influence inflammation and angiogenesis-two of the histologic signatures of Kaposi's sarcoma (Moore et al. 1996; Boshoff et al. 1997; Neipel et al. 1997; Nicholas et al. 1997; Bais et al. 1998). Therefore, Notch-mediated induction of such genes could contribute to KS pathogenesis even in the absence of viral spread.

\section{Materials and methods}

\section{Cell lines}

BCBL-1 cells were grown in RPMI 1640 medium supplemented with $10 \%$ fetal bovine serum (FBS), $2 \mathrm{mM}$ penicillin, streptomycin and L-glutamine, $1 \mathrm{mM}$ sodium bicarbonate, and 0.05 $\mathrm{mM}$ 2-mercaptoethanol. SLK and 293T cells were grown in DMEM supplemented with $10 \%$ FBS. Mouse RBPJ $\kappa^{-1-}$ (OT11) and wild-type (OT13) fibroblast cell lines were kindly provided by $\mathrm{T}$. Honjo, and were grown in high-glucose DMEM supplemented with $10 \%$ FBS and $100 \mathrm{U}$ of mouse interferon gamma (Life Technologies) per $\mathrm{mL}$ at $32^{\circ} \mathrm{C}$.

\section{Plasmids}

The full-length RTA (1-691 aa) or 50دSTAD (1-530 aa) coding sequence, obtained by PCR using $5^{\prime}$ primer $\left(5^{\prime}\right.$-GCGCGAA TTCATGGCGCAAGATGACAAGGGTAAG- ${ }^{\prime}$ ) and $3^{\prime}$ primer (5'-GCGCGTCGACTCAGTCTCGGAAGTAATTACGCCA-3' or 5'-GCGCGTCGACTCACTTACGCTTCTTTGAGCTCCTC TC-3') from template pcDNA3-Flc50 (Lukac et al. 1998), was inserted into pBD-Gal4-Cam (Clontech) at the EcoRI and XhoI sites. These two plasmids, pBD-Gal4-50 and pBD-Gal4$50 \Delta$ STAD, were used in yeast two-hybrid screening as baits.

The pV5-50 SSTAD, encoding 1 to 530 aa of RTA with Cterminal V5 tag, was described before (Lukac et al. 1999). The RBP-Jк expression vector, pcDNA3.1-RBPJк, was constructed by amplifying the full-length RBP-JK cDNA from an EST clone (ATCC5361098) using 5' primer (5'-AATTGGATCCCCAC CATGGACCACACGGAGGGCT- $\left.3^{\prime}\right)$ and $3^{\prime}$ primer $\left(5^{\prime}\right.$-AAT TCTCGAGTTAGGATACCACTGTGGCT-3'), and inserted into pcDNA3.1 (Invitrogen) at the BamHI and XhoI sites. The Flag-tagged RBP-JK was made by PCR with $5^{\prime}$ primer containing Flag sequence (DYKDDDDK) and cloned into pcDNA3.1 vector at the BamHI and XhoI sites to create pFlag-RBPJк.

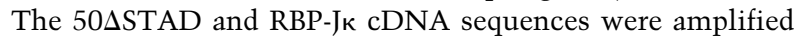
from parental vectors, pcDNA3-Flc50 and pcDNA3.1-RBPJк, and cloned into pGEX-4T-1 (Amersham Pharmacia). The result-

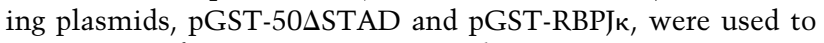
express GST fusion proteins in E. coli.

Three copies of the wild-type (5'-GATCTGGTGTAAACAC GCCGTGGGAAAAAATTTATG-3') or mutant (5'-GATCTG GTGTAAACACGGGCTTGGAAAAAATTTATG-3') RBP-Jк recognition sequences (WT underlined, mutated nucleotides in bold) were cloned into pGL3-promoter (Promega) at a BgIII site, $120 \mathrm{bp} 5^{\prime}$ to a basal SV40 promoter-driven luciferase reporter gene, to make pGL3-3 $\times$ RBP-Jk or pGL3-3 $\times$ RBP-Jкmut. Likewise, four copies of the wild-type or three copies of mutant RBP-Jк recognition sequences were cloned in opposite orientation to generate pGL3-4 $\times$ RBPJк (rev) or pGL3-3 $\times$ RBPJкmut(rev).

pGL3-PAN1450 (also called pGL3-nut-1), pGL3-DBP, and pGL3-MTA (also called pGL3-ORF57D5) were described before (Lukac et al. 1999). pGL3-PAN706 was created by digestion of SmaI-cut pGL3-PAN1450 with Tth III followed by blunt end ligation. pGL3-PAN1450-50RE and pGL3-PAN706-50RE were generated by linker scanning mutations of parental pGL3PAN1450 and pGL3-PAN706, replacing the 12-nt sequence (-67 to -56 upstream of PAN RNA start site) with linker sequence TATCATATGATA.

Mutations of RBP-JK recognition sequence in the promoters of MTA, SSB, and PAN were made by Quick-change Site-directed Mutagenesis (Stratagene). The paired PCR primers were designed to contain mutations in RBP-JK recognition sequence (underlined were changed nucleotides): 5'-GTGTAACAAT AATGTTCCAAGCCCCCATTTTTCGTTTGTGG-3' for MTA promoter from -95 to -55 upstream of RNA start site; $5^{\prime}$ GTATAAAATACGCGTCTTGGAAAGCGACAGAAGG-3' for SSB promoter from -216 to -183 upstream of ATG start codon; and 5'-CGATCAGTGTACCATATTCCAAGCACCCATCAAC ACCGCTGC-3' for PAN promoter from -837 to -796 upstream of RNA start site.

Truncated constructs of RBPJK (AF, AG, AH, AB, AC, AD, BE, $\mathrm{BF}, \mathrm{BG}, \mathrm{EE}$, and $\mathrm{CE}$, schematically shown in Fig. 4) and RTA (AF, AG, BE, BF, DE, and $\mathrm{CE}$, schematically shown in Fig. 5) were constructed by amplifying corresponding cDNA fragments (sequences of PCR primers will be provided upon request) and cloned into pcDNA3.1 under T7 promoter.

All constructs and mutations were verified by DNA sequencing.

\section{Yeast two-hybrid screening}

pBD-Gal4-50 STTAD, expressing truncated Rta (1 to 530 aa) fused to Gal4 binding domain, was used as bait to screen a placental cDNA library (Clontech) and a cDNA library con- 
structed from TPA-induced BCBL-1 cells (A. Polson and D. Ganem, unpubl.). Yeast reporter strain HF7C was transformed simultaneously with pBD-Gal4-50 $\mathrm{STAD}$ and the cDNA library. $\mathrm{His}^{+}$colonies were screened for $\beta$-galactosidase activity by filter lift assay. Plasmids were retrieved from $\mathrm{His}^{+}, \mathrm{LacZ}^{+}$ colonies and selected in $E$. coli $\mathrm{DH} 10 \mathrm{~B}$ with ampicillin resistance. To eliminate possible false positives, plasmid DNA rescued from yeast transformants was retransformed into yeast reporter strain Y187 either alone or paired with pBD-Gal4$50 \Delta$ STAD. DNA and protein sequence analyses and homology searches were performed with the BLAST program.

\section{Coimmunoprecipitation}

$293 \mathrm{~T}$ cells grown in 10-cm plates were transfected with either

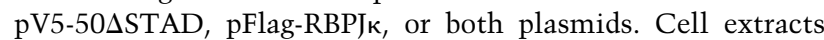
prepared using RIPA buffer $(1 \times$ PBS, $1 \%$ NP- $40,0.5 \%$ sodium deoxycholate, $0.1 \%$ SDS) supplemented with complete protease inhibitor cocktail (Roche) were incubated with mouse antiFLAG monoclonal antibody $\mathrm{m} 2$ (Sigma) for $1 \mathrm{~h}$ on ice. Thirty microliters of protein $\mathrm{A} / \mathrm{G}$-agarose (Santa Cruz) were added and incubation was continued at $4^{\circ} \mathrm{C}$ overnight with rotation. Beads were washed four times with $1 \mathrm{~mL}$ of cold PBS buffer and boiled in Laemmli sample buffer for $5 \mathrm{~min}$. Immunoprecipitated proteins were separated by SDS-PAGE and detected by immunoblotting with mouse anti-V5 monoclonal antibody (Invitrogen). Endogenous coimmunoprecipitation was performed in BCBL-1 cells. Uninduced or TPA-induced BCBL-1 cells were lysed with RIPA buffer. Immunoprecipitation and subsequent Western blot were essentially the same as described above, except for using rabbit anti-RВPJк polyclonal antibody (Cemine) in immunoprecipitation and rabbit anti-ORF50 antiserum (Lukac et al. 1998) in Western blot. As a control for endogenous coimmunoprecipitation, OT11 $\left(\mathrm{RBP}_{\mathrm{K}} \mathrm{K}^{-/-}\right)$cells were transfected with pcDNA3-Flc50. Cell lysates were immunoprecipitated with anti-RВPJк antibody and Western blotted with anti-ORF50 antiserum.

\section{Luciferase and $\beta$-galactosidase assays}

Cells were plated onto 6-well dishes and grown to $70 \%-80 \%$ confluence. DNA transfection was performed using Fugene 6 (Roche) according to the manufacturer's protocol. For each transfection, $0.5 \mu \mathrm{g}$ of reporter plasmid and 0 to $1.5 \mu \mathrm{g}$ of transactivator were used, and total DNA was normalized to $2 \mu \mathrm{g}$ with vector pcDNA3.1. pcDNA3.1-lacZ was also included in each transfection as an internal control, and $\beta$-galactosidase assay was performed as instructed (Promega). Cell extracts were prepared and subjected to luciferase assay using a Luciferase Assay Kit (Promega). Each luciferase assay was done in duplicate on at least two independent experiments.

\section{Purification of GST-fusion proteins and GST pull-down assay}

Bacterially expressed GST, GST-50دSTAD, or GST-RBPJк fusion protein was purified as described (Frangioni and Neel 1993). For in vitro translation of RBP-JK or RTA fragments, the TNT T7 Quick-coupled transcription/translation system (Promega) was used. A $50-\mu \mathrm{L}$ reaction contains $2 \mu \mathrm{g}$ of DNA and L- $\left[{ }^{35} \mathrm{~S}\right] \mathrm{me}-$ thionine. After incubation at $37^{\circ} \mathrm{C}$ for $3 \mathrm{~h}, 20 \mu \mathrm{L}$ of reaction was added to $200 \mu \mathrm{L}$ of NETN buffer (20 mM Tris at pH7.5, $100 \mathrm{mM}$ $\mathrm{NaCl}, 1 \mathrm{mM}$ EDTA, 0.5\% Nonidet P-40) supplemented with protease inhibitors (Roche), which contained either GST or GST fusion protein. Twenty microliters of Glutathione-Sepharose 4B beads (Amersham Pharmacia) was added to reaction and incubated at $4^{\circ} \mathrm{C}$ overnight with rotation. Beads were washed four times with NETN buffer and boiled in Laemmli sample buffer. After separation by SDS-PAGE, gels were fixed in $10 \%$ acetic acid, washed with water, treated with Fluoror (DuPont) for $1 \mathrm{~h}$, dried, and analyzed by autoradiography.

\section{Recombinant protein expression}

Rabbit reticulocyte lysate (RRL)-derived proteins (also referred to in the text and in figure legends as RRL proteins) were synthesized with the TNT T7 Quick Coupled Transcription/Translation System (Promega). Extracts were programmed with $2 \mu \mathrm{g}$ total supercoiled DNA.

\section{Electromobility shift assays (EMSA)}

$\left[{ }^{32} \mathrm{P}\right]$-labeled probes were synthesized via Klenow fill-in reaction and purified with Microspin G25 columns (Amersham Pharmacia) as described (Lukac. et al. 2001). Radioactive probes were diluted in water to a final concentration of $105 \mathrm{cpm} / \mu \mathrm{L}$. DNA binding reactions were performed in a manner similar to that described (Lukac et al. 2001). Briefly, proteins from RRL were mixed with $1 \mu \mathrm{g}$ poly (dI-dC) (Sigma) in $1 \times$ DNA binding buffer for $30 \mathrm{~min}$ on ice. Next, $1 \mu \mathrm{L}$ of labeled probe was added to each reaction, and the tubes were incubated at $14^{\circ} \mathrm{C}-16^{\circ} \mathrm{C}$ for $30 \mathrm{~min}$. DNA-protein complexes were resolved via nondenaturing PAGE, using $4 \%$ polyacrylamide gels. The gel was run in $1 \times$ Tris-Gly-EDTA buffer at a constant current of $25 \mathrm{~mA}$. Following electrophoresis, the gel was transferred to Whatman paper, and dried for $1 \mathrm{~h}$ at $80^{\circ} \mathrm{C}$. Unless otherwise noted, dried gels were exposed to Bio-Max MS autoradiography film (Kodak) for $14-18 \mathrm{~h}$ at $-70^{\circ} \mathrm{C}$ with an intensifying screen. Competitive EMSA experiments were performed as described above, except with the addition of a 20 -fold molar excess of unlabeled probe to the protein-poly (dI-dC) mix before the incubation on ice.

\section{Acknowledgments}

We thank Dr. T. Honjo for providing the RBP-Jк null cell line, Dr. A. Polson for the yeast two-hybrid cDNA library from activated BCBL-1 cells, and Dr. A. Grundhoff for yeast cell lines. D.G. is an investigator of the Howard Hughes Medical Institute.

The publication costs of this article were defrayed in part by payment of page charges. This article must therefore be hereby marked "advertisement" in accordance with 18 USC section 1734 solely to indicate this fact.

\section{References}

Ambroziak, J.A., Blackbourn, D.J., Herndier, B.G., Glogau, R.G., Gullett, J.H., McDonald, A.R., Lennette, E.T., and Levy, J.A. 1995. Herpes-like sequences in HIV-infected and uninfected Kaposi's sarcoma patients. Science 268: 582-583.

Ansieau, S., Strobl, L.J., and Leutz, A. 2001. Activation of the Notch-regulated transcription factor CBF1/RBP-Jк through the 13SE1A oncoprotein. Genes \& Dev. 15: 380-385.

Aster, J. and Pear, W. 2001. Notch signaling in leukemia. Curr. Opin. Hematol. 8: 237-244.

Bais, C., Santomasso, B., Coso, O., Arvanitakis, L., Raaka, E.G., Gutkind, J.S., Asch, A.S., Cesarman, E., Gershengorn, M.C., Mesri, E.A., et al. 1998. G-protein-coupled receptor of Kaposi's sarcoma-associated herpesvirus is a viral oncogene and angiogenesis activator. Nature 391: 86-89.

Blackbourn, D.J., Lennette, E., Klencke, B., Moses, A., Chandran, B., Weinstein, M., Glogau, R.G., Witte, M.H., Way, D.L., Kutzkey, T., et al. 2000. The restricted cellular host 
range of human herpesvirus 8. AIDS 14: 1123-1133.

Boshoff, C. and Weiss, R.A. 1998. Kaposi's sarcoma-associated herpesvirus. Adv. Cancer Res. 75: 57-86.

Boshoff, C., Schulz, T.F., Kennedy, M.M., Graham, A.K., Fisher, C., Thomas, A., McGee, J.O., Weiss, R.A., and O'Leary, J.J. 1995. Kaposi's sarcoma-associated herpesvirus infects endothelial and spindle cells. Nat. Med. 1: 1274-1278.

Boshoff, C., Endo, Y., Collins, P.D., Takeuchi, Y., Reeves, J.D., Schweickart, V.L., Siani, M.A., Sasaki, T., Williams, T.J., Gray, P.W., et al. 1997. Angiogenic and HIV-inhibitory functions of KSHV-encoded chemokines. Science 278: 290-294.

Capobianco, A.J., Zagouras, P., Blaumueller, C.M., ArtavanakisTsakonas, S., and Bishop, J.M. 1997. Neoplastic transformation by truncated alleles of human Notch/Tan1 and Notch2. Mol. Cell Biol. 17: 6265-6273.

Cheng, E.H., Nicholas, J., Bellows, D.S., Hayward, G.S., Guo, H.G., Reitz, M.S., and Hardwick, J.M. 1997. A Bcl-2 homolog encoded by Kaposi sarcoma-associated virus, human herpesvirus 8 , inhibits apoptosis but does not heterodimerize with Bax or Bak. Proc. Natl. Acad. Sci. 94: 690-694.

Ensoli, B. and Sturzl, M. 1998. Kaposi's sarcoma: A result of the interplay among inflammatory cytokines, angiogenic factors and viral agents. Cytokine Growth Factor Rev. 9: 63-83.

Flemington, E.K. 2001. Herpesvirus lytic replication and the cell cycle: Arresting new developments. J. Virol. 75: 4475-4481.

Frangioni, J.V. and Neel, B.G. 1993. Solubilization and purification of enzymatically active glutathione S-transferase (pGEX) fusion proteins. Anal. Biochem. 210: 179-187.

Gradoville, L., Gerlach, J., Grogan, E., Shedd, D., Nikiforow, S., Metroka, C., and Miller, G. 2000. Kaposi's sarcoma-associated herpesvirus open reading frame 50/Rtaprotein activates the entire viral lytic cycle in the HH-B2 primary effusion lymphoma cell line. J. Virol. 74: 6207-6212.

Grossman, S.R., Johannsen, E., Tong, X., Yalamanchili, R., and Kieff, E. 1994. The Epstein-Barr virus nuclear antigen 2 transactivator is directed to response elements by the Jк recombination signal binding protein. Proc. Natl. Acad. Sci. 91: 7568-7572.

Henkel, T., Ling, P., Hayward, S.D., and Peterson, M.G. 1994. Mediation of Epstein-Barr virus EBNA2 transactivation by recombination signal binding protein Jk. Science 265: 92-95.

Hsieh, J.J. and Hayward, S.D. 1995. Masking of the CBF1/RBPJא transcriptional repression domain by Epstein-Barr virus EBNA2. Science. 268: 560-563.

Hsieh, J.J., Henkel, T., Salmon, P., Robey, E., Peterson, M.G., and Hayward, S.D. 1996. Truncated mammalian Notch1 activates CBF1/RBPJk-repressed genes by a mechanism resembling that of Epstein-Barr virus EBNA2. Mol. Cell Biol. 16: 952-959.

Hsieh, J.J., Nofziger, D.E., Weinmaster, G., and Hayward, S.D. 1997. Epstein-Barr virus immortalization: Notch2 interacts with CBF1 and blocks differentiation. I. Virol. 71: 1938-1945.

Hsieh, J.J., Zhou, S., Chen, L., Young, D.B., and Hayward, S.D. 1999. CIR, a corepressor linking the DNA binding factor CBF1 to the histone deacetylase complex. Proc. Natl. Acad. Sci. 96: 23-28.

Johannsen, E., Koh, E., Mosialos, G., Tong, X., Kieff, E., and Grossman, S.R. 1995. Epstein-Barr virus nuclear protein 2 transactivation of the latent membrane protein 1 promoter is mediated by Jк and PU.1. J. Virol. 69: 253-262.

Johannsen, E., Miller, C., Grossman, S., and Kieff, E. 1996. EBNA2 and EBNA 3C extensively and mutually exclusively associate with RBP-Jк in EBV-transformed B lymphocytes. J. Virol. 70: 4179-4183.

Kao, H.Y., Ordentlich, P., Koyano-Nakagawa, N., Tang, Z., Downes, M., Kintner, C.R., Evans, R.M., and Kadesch, T.
1998. A histone deacetylase corepressor complex regulates the Notch signal transduction pathway. Genes \& Dev. 12: $2269-2277$.

Kurooka, H. and Honjo, T. 2000. Functional interaction between the mouse notch 1 intracellular region and histone acetyltransferases PCAF and GCN5. T. Biol. Chem. 275: 17211-17220.

Ling, P.D., Hsieh, J.J., Ruf, I.K., Rawlins, D.R., and Hayward, S.D. 1994. EBNA-2 upregulation of Epstein-Barr virus latency promoters and the cellular CD23 promoter utilizes a common targeting intermediate, CBF1. J. Virol. 68: 53755383.

Lukac, D.M., Renne, R., Kirshner, J., and Ganem, D. 1998. Reactivation of Kaposi's sarcoma-associated herpesvirus from latency by expression of the orf 50 transactivator, a homolog of the EBV R protein. Virology 252: 304-312.

Lukac, D.M., Kirshner, J., and Ganem, D. 1999. Transcriptional activation by the ORF 50 protein of KSHV/HHV-8 is required for lytic viral reactivation in B cells. J. Virol. 73: 93489361.

Lukac, D.M., Garibyan, L., Kirshner, J., Palmeri, D., and Ganem, D. 2001. DNA binding by the Kaposi's sarcoma-associated herpesvirus lytic switch protein is necessary for transcriptional activation of two viral delayed early promoters. J. Virol. 75: 6786-6799.

Martin, D.F., Kuppermann, B.D., Wolitz, R.A., Palestine, A.G., Li, H., and Robinson, C.A. 1999. Oral ganciclovir for patients with cytomegalovirus retinitis treated with a anciclovir implant. N. Engl. J. Med. 340: 1063-1070.

Moore, P.S., Boshoff, C., Weiss, R.A., and Chang, Y. 1996. Molecular mimicry of human cytokine and cytokine response pathway genes by KSHV. Science 274: 1739-1744.

Morimura, T., Goitsuka, R., Zhang, Y., Saito, I., Reth, M., and Kitamura, D. 2000. Cell cycle arrest and apoptosis induced by Notch1 in B cells. J. Biol. Chem. 275: 36523-36531.

Mumm, J.S. and Kopan, R. 2000. Notch signaling: From the outside in. Dev. Biol. 228: 151-165.

Neipel, F., Albrecht, J.C., Ensser, A., Huang, Y.Q., Li, J.J., Friedman-Kien, A.E., and Fleckenstein, B. 1997. Human herpesvirus 8 encodes a homolog of interleukin-6. J. Virol. 71: 839842.

Nicholas, J., Ruvolo, V.R., Burns, W.H., Sandford, G., Wan, X., Ciufo, D., Hendrickson, S.B., Guo, H.G., Hayward, G.S., and Reitz, M.S. 1997. Kaposi's sarcoma-associated human herpesvirus- 8 encodes homologues of macrophage inflammatory protein-1 and interleukin-6. Nat. Med. 3: 287-292.

Oka, C., Nakano, T., Wakeham, A., de la Pompa, J.L., Mori, C., Sakai, T., Okazaki, S., Kawaichi, M., Shiota, K., Mak, T.W., et al. 1995. Disruption of the mouse RBP-JK gene results in early embryonic death. Development 121: 3291-3301.

Oswald, F., Tauber, B., Dobner, T., Bourteele, S., Kostezka, U., Adler, G., Liptay, S., and Schmid, R.M. 2001. p300 acts as a transcriptional coactivator for mammalian Notch-1. Mol. Cell Biol. 21: 7761-7774.

Panin, V.M. and Irvine, K.D. 1998. Modulators of Notch signaling. Semin. Cell Dev. Biol. 9: 609-617.

Quinlivan, E.B., Holley-Guthrie, E.A., Norris, M., Gutsch, D., Bachenheimer, S.L., and Kenney, S.C. 1993. Direct BRLF1 binding is required for cooperative BZLF1/BRLF1 activation of the Epstein-Barr virus early promoter, BMRF1. Nucleic Acids Res. 21: 1999-2007.

Ragoczy, T., Heston, L., and Miller, G. 1998. The Epstein-Barr virus Rta protein activates lytic cycle genes and can disrupt latency in B lymphocytes. J. Virol. 72: 7978-7984.

Russo, J.J., Bohenzky, R.A., Chien, M.C., Chen, J., Yan, M., Maddalena, D., Parry, J.P., Peruzzi, D., Edelman, I.S., Chang, 
Y., et al. 1996. Nucleotide sequence of the Kaposi sarcomaassociated herpesvirus (HHV8). Proc. Natl. Acad. Sci. 93: $14862-14867$.

Sarid, R., Olsen, S.J., and Moore, P.S. 1999. Kaposi's sarcomaassociated herpesvirus: Epidemiology, virology, and molecular biology. Adv. Virus Res. 52: 139-232.

Sarid, R., Sato, T., Bohenzky, R.A., Russo, J.J., and Chang, Y. 1997. KSHV encodes a functional bcl-2 homolog. Nat. Med. 3: 293-297.

Seaman, W.T., Ye, D., Wang, R.X., Hale, E.E., Weisse, M., and Quinlivan, E.B. 1999. Gene expression from the ORF50/K8 region of Kaposi's sarcoma-associated herpesvirus. Virology 263: 436-449.

Schulz, T.F. 1999. Epidemiology of Kaposi's sarcoma-associated herpesvirus/human herpesvirus 8. Adv. Cancer Res. 76: $121-160$.

Song, M.J., Brown, H.J., Wu, T.T., and Sun, R. 2001. Transcription activation of polyadenylated nuclear RNA by RTA in human herpesvirus 8/Kaposi's sarcoma-associated herpesvirus. J. Virol. 75: 3129-3140.

Staskus, K., Zhong, W., Gebhardt, K., Herndier, B., Wang, H., Renne, R., Beneke, J., Pudney, J., Anderson, D., Ganem, D., et al. 1997. Kaposi's sarcoma-associated herpesvirus gene expression in endothelial (spindle) tumor cells of Kaposi's sarcoma. J. Virol. 71: 715-719.

Sun, R., Lin, S.F., Gradoville, L., Yuan, Y., Zhu, F., and Miller, G. 1998. A viral gene that activates lytic cycle expression of Kaposi's sarcoma-associated herpesvirus. Proc. Natl. Acad. Sci. 95: 10866-10871.

Tani, S., Kurooka, H., Aoki, T., Hashimoto, N., and Honjo, T. 2001. The N- and C-terminal regions of RBP-J interact with the ankyrin repeats of Notch1 RAMIC to activate transcription. Nucleic Acids Res. 29: 1373-1380.

Tun, T., Hamaguchi, Y., Matsunami, N., Furukawa, T., Honjo, T., and Kawaichi, M. 1994. Recognition sequence of a highly conserved DNA binding protein RBP-Јк. Nucleic Acids Res. 22: $965-971$.

Waltzer, L., Perricaudet, M., Sergeant, A., and Manet, E. 1996. Epstein-Barr virus EBNA 3A and 3C proteins both repress RBP-Јк-EBNA2-activated transcription by inhibiting the binding of RBP-Jк to DNA. J. Virol. 70: 5909-5915.

Wang, S., Liu, S., Wu, M.H., Geng, Y., and Wood, C. 2001. Identification of a cellular protein that interacts and synergizes with the RTA (ORF50) protein of Kaposi's sarcoma-associated herpesvirus in transcriptional activation. I. Virol. 75: 11961-11973.

Weinmaster, G. 2000. Notch signal transduction: A real rip and more. Curr. Opin. Genet. Dev. 10: 363-369.

Zalani, S., Holley-Guthrie, E., and Kenney, S. 1996. Epstein-Barr viral latency is disrupted by the immediate-early BRLF1 protein through a cell-specific mechanism. Proc. Natl. Acad. Sci. 93: 9194-9199.

Zhao, B., Marshall, D., and Sample, C. 1996. A conserved domain of EBV nuclear antigens $3 \mathrm{~A}$ and $3 \mathrm{C}$ binds to a discrete domain of Jк. J. Virol. 70: 4228-4236. 


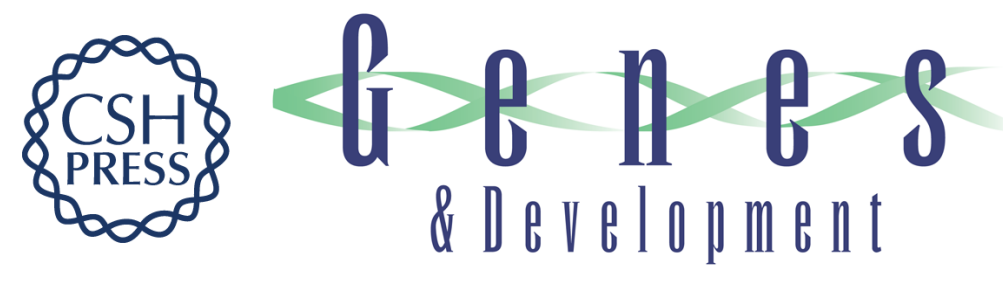

\section{The lytic switch protein of KSHV activates gene expression via functional interaction with RBP-J $\kappa(C S L)$, the target of the Notch signaling pathway}

Yuying Liang, Jean Chang, Stephen J. Lynch, et al.

Genes Dev. 2002, 16:

Access the most recent version at doi:10.1101/gad.996502

\section{References This article cites 53 articles, 34 of which can be accessed free at: http://genesdev.cshlp.org/content/16/15/1977.full.html\#ref-list-1}

License $\begin{array}{cl}\text { Email Alerting } & \begin{array}{l}\text { Receive free email alerts when new articles cite this article - sign up in the box at the top } \\ \text { right corner of the article or click here. }\end{array}\end{array}$

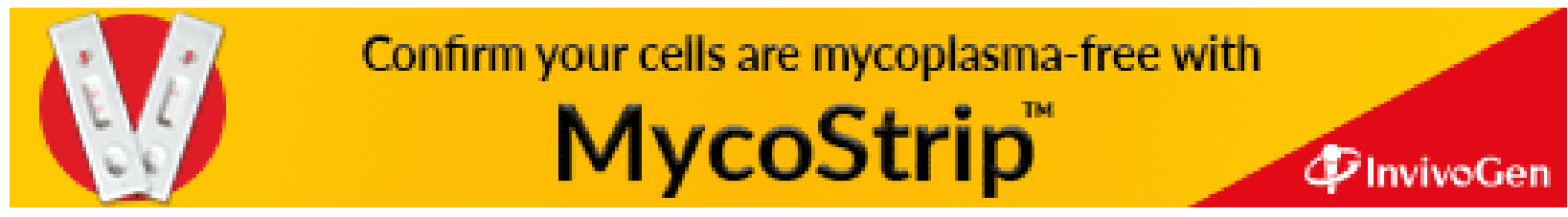

